Vickers Armstrong for cruises and for service on routes between England and Australia. Its gross tonnage is 23,445 and it will accommodate 463 firstclass and 605 tourist passengers and a crew of 466 . Steam is provided by six oil-fired Babcock and Wilcox boilers. Pipes conduct it to two sets of 1,715 revs. per min. Parsons turbines. These drive the propellers at 112 r.p.m. by means of mechanical gearing. Two systems of intercommunication telephones are installed. The Marconi International Communication Co. has installed an all-wave radio installation, including a direction finder, and an 'echometer' depth sounder, together with a broadcast system of loud speakers throughout the vessel. Time is given by means of 82 synchronous clocks. A portable sound picture equipment by the Western Electric Co. is one of the many forms of entertainment provided.

\section{The Problem of Dates of Publication}

THE study of natural history has branched into many side-lines; but it is strange to think how far off the direct line of acquisition of nature knowledge the need for accuracy has led. For the convenience of naturalists the world over, animals and plants bear specific names, and the proper name where several have been given is determined conventionally by priority of christening. But so difficult is it in some cases to determine priority that an extensive literature has developed around these knotty problems, and so insistent is the demand for accuracy that a Society for the Bibliography of Natural History has been formed. The first part of its Journal is a catalogue of papers concerning the dates of publication of natural history books, arranged in alphabetical order of the authors of the books, and this ought to be of great service to systematists. Sometimes it is difficult to see exactly how the alphabetical order has been determined; "Ent. Soc. Lond." appears under "London", "Ent. Soc. N. S. Wales" under "Ent." ; "Royal Phys. Soc. Edinburgh" appears under "Proc.", while the Wernerian Society of the same city appears under "Edinburgh". Doubtless there are sound reasons for this grouping, but they are not obvious, and they are not set out in the very brief introductory notes. The Society maintains a card index of papers concerned with the dates of publication of natural history books, and copies of such papers will be welcomed by the Secretary at 41 Queen's Gate, London, S.W.7.

\section{Empire Grants Committee for Museums}

THE final report to the Carnegie Corporation of New York on the activities of the Empire Grants Committee appears in the Museums Journal of May. It is a stimulating document. On April 1, 1934, the Committee was set up to administer a fund of 54,000 dollars granted by the Carnegie Corporation of New York for Colonial Museums, with an addition of 9,000 dollars for expenses, $£ 12,550$ in all. All museums in the British Colonies, and in Newfoundland and Southern Rhodesia were invited to submit applica- tions for grants; forty applications were received and twenty-five grants were made. They ranged from $£ 60$ to Kandy Museum and Bermuda Historical Museum to $£ 1,000$ for Nairobi, Cyprus, Barbados, Singapore, Zanzibar, Jamaica. Various strict regulations had to be made as to the conditions upon which grants could be made; but the Committee is satisfied that the effect of grants has been in nearly every instance most stimulating to the local museum movement. At Bulawayo and Salisbury, the museums have been elevated to the dignity of national museums; in Cyprus, Barbados and Antigua more attractive premises and added Government recognition have been gained; but in most cases grants have been given for cases and equipment, so that museum interiors have been brightened and organized on modern lines. The success of the experiment leads the Committee to suggest that there are good reasons for continuing so promising a first effort.

\section{Time Measurement}

THE history and development of time measurement have already been described in a Science Museum Handbook ("Time Measurement", Part 1). The second part of the handbook which has recently been issued (London: H.M. Stationery Office. 2s. net) contains a detailed description of the objects in "The Time Measurement Collection at the Science Museum, South Kensington". The exhibits, ranging from the ancient Egyptian shadow clocks and water clocks to modern electric time-keepers, include sundials, mechanical clocks, watches and chronometers, escapement models and chronographs, as well as various auxiliary devices such as striking mechanisms, time recorders and time switches. Introductory remarks to each chapter explain the system of classification adopted, and outline the general principles involved in the respective groups of instruments. Many of the exhibits at the Science Museum are shown in continuous operation, while others can be operated by visitors-a facility that appears to receive perpetual appreciation. In addition, several of the more delicate watch mechanisms are illustrated by largescale models. It may be noted that Harrison's four marine timekeepers (the fourth, completed in 1759 , being the chronometer which won for Harrison the British Government prize of $£ 20,000$ ) are now represented in the Museum only by photographs, the originals themselves, long associated with the Royal Observatory, Greenwich, having been transferred to the National Maritime Museum at Greenwich. This handbook with its numerous illustrations provides an admirable introduction to a study of the Time Measurement Collection, and it will also serve as a useful handbook of reference for other occasions.

\section{Meteorology in India}

THE Meteorological Department of the Government of India has for several years had to contend with serious financial obstacles in the shape of reduced grants, when the increasing requirements of aviation have demanded increased departmental activity. The 